\title{
KOMUNIKASI KONSULTATIF PENYULUH AGAMA ISLAM DI DAERAH PERBATASAN KALIMANTAN BARAT
}

\author{
Bob Andrian \\ Dosen IAIN Pontianak \\ bobandriansbs@gmail.com
}

\begin{abstract}
Religious Intructor is one of the spearheads of the government, especially the Ministry of Religion, to provide guidance and counseling to the community. Islamic Religius Instructors are also a profession that has a significant role in communicating Islamic values to the wider community, especially Muslim communities in border areas that have limited access to urban centers. The person is called an Instructor, both functional, honorary religious counselors and someone who carries out voluntary guidance and counseling (Volunteer) work. In addition, religious counselors are also mentioned by some experts that "Religious Instructors are Attackers, The Lamp in the midst of darkness, that gives enlightenment and teach wisdom to the surrounding community". Based on this statement, it can be described that the Religious Instructor is like a lamp that light in the midst of the great threat and challenge to national morality. According to the Joint Decree of the Indonesian Ministery of Religion and the Head of the State staffing Agency number 574 and 178 of 1999, it states that there are three functions of religious instructors, namely; Informative and educative functions, consultative functions, and advocative functions. Therefore, it is quite interesting to conduct a comprehensive study of how communication is carried out by Islamic Religious Instructors in providing enlightenment and providing Consulative guidance to the development community, including those that occur in border areas, particularly in Sajingan Besar District, Sambas Regency, West Borneo.
\end{abstract}

Keywoard: Communication, Religious Intructor, Religious Intructor, Border Areas. 


\section{A. Pendahuluan}

Keberadaan Kementerian Agama sejak awal sampai saat ini, sudah banyak sekali melakukan peningkatan dan perubahan kebijakan. Setiap peningkatan dan perubahan kebijakan tersebut pada dasarnya bukanlah hal baru yang datang tiba-tiba, tetapi merupakan sebuah tindakan preventif dari Kementerian Agama RI khususnya Ditjen Bimas Islam. Tujuan substansinya ialah untuk merespon dinamika kehidupan keberagamaan masyarakat yang ada di Indonesia umumnya. Mengingat kondisi sosial masyarakat Indonesia yang semakin hari terus berkembang begitu komplek, serta banyak isu-isu nasional yang melibatkan persoalan agama, suku, ras dan golongan. Sehingga tugas dan fungsi lembaga pemerintahan khususnya Bimas Islam dituntut ikut ditingkatkan terkait profesionalitas penyuluh agama dalam menegakkan nilai-nilai moralitas demi tegaknya NKRI.

Mengutip pernyataan Muhammadiyah Amin dalam Prakata Redaksi dalam Majalah yang diterbitkan oleh Kementerian Agama dengan judul "Jejak Sunyi Penyuluh Agama" menyebutkan bahwa perubahan Kebijakan yang dilakukan oleh pemerintah khususnya Ditjen Bimas Islam beberapa tahun terakhir terbukti telah berhasil melakukan peningkatan kualitas layanan dalam beberapa tugas dan fungsi pokok penyuluh agama. ${ }^{1}$ Regulasi menegaskan kembali, bahwa pada tahun 2016 yang lalu kembali melakukan perubahan. Perubahan yang dilakukan seperti merevitalisasi tentang peraturan KUA dan Kepenghuluan, yang sebelumnya proses menikahkan masih dilimpahkan kepada Penghulu, namun sekarang ini semua urusan pernikahan ditugas fungsikan kepada KUA yang ada di masing-masing kecamatan.

Selanjutnya, Muhammadiyah Amin menegaskan bahwa perubahan tersebut dilakukan ialah untuk lebih memfokuskan pada kebijakan tentang penyuluh agama Islam, yaitu menjelaskan beberapa hal menyangkut tentang Penyuluh Agama Islam dalam memberikan bimbingan dan penyuluhan keagamaan kepada masyarakat secara keseluruahan tanpa

1 Direktorat Jendral Bimbingan Masyarakat Islam, Jejak Sunyi Penyuluh Agama,..., h. 6 
terkecuali masyarakat di daerah-daerah perbatasan. ${ }^{2}$ Adapun semua kebijakan tersebut tertuang dalam regulasi yang sah sesuai aturan yang berlaku.

Peraturan dan kebijakan tentang penyuluh agama pada dasarnya bukanlah hal yang baru dalam birokrasi pemerintahan, namun merupakan hal yang sudah lama, bahkan sudah ada sejak dekade awal keberadaan Kementerian agama. Pada dekade sebelumnya, yaitu pada masa Menteri Agama RI Pertama (H.M Rasjidi) tahun 1946 tugas dan fungsi penyuluh agama ditangani langsung oleh Direktorat Penerangan Agama, bagian Penyiaran, Penyelidikan dan Kebudayaan. Tidak lama kemudian istilah tersebut diganti dengan lebih spesifik menjadi Bagian Penyiaran dan Penerangan. ${ }^{3}$

Adapun dekade berikutnya, yaitu tepatnya pada bulan November tahun 1948 (dengan K.H Masjkur) sebagai Menteri Agama RI masa itu, membuat kebijakan dan memutuskan bahwa dibentuk Bagian Penerangan atau Penyiaran Agama pada masing-masing jawatan di daerah-daerah. ${ }^{4}$ Kemudian pada periode inilah, mulai ditingkatknnya peran dan tugas penyiaran dan penerangan dalam menjaga semangat patriotisme bangsa dalam menjaga kedaulatan negara Indonesia di seleuruh daerah NKRI. Sehingga selanjutnya peran dan fungsi penyuluh agama terus berkembang sampai saat ini, yaitu dikenal dengan istilah yang beragam pula, mulai dari istilah Guru Agama Honorer (GAH) sampai pada istilah Penyuluh Agama PNS dan Penyuluh Agama Honorer (PAH). Ditambah lagi dengan adanya Peraturan Pemerintah No 16 Tahun 1994 tentang Jabatan Fungsional Pegawai Negeri Sipil, yang menyebutkan bahwa untuk meningkatkan kualitas dan profesionalitas penyuluh agama dalam pembinaan karier pegawai negeri sipil perlu ditetapkan

2Direktorat Jendral Bimbingan Masyarakat Islam, Jejak Sunyi Penyuluh Agama..., h. 6

${ }^{3}$ Kementerian Agama pada periode awal adalah terdiri dari beberapa Direktorat, yaitu Direktorat Urusan Agama, Direktorat Pendidikan Agama, dan Direktorat Peradilan Agama. Periode in berlangsung selama kurnag lebih 10 tahun. Lihat, Majalah Ditjen Bimans Islam dengan Judul "Jejak Sunyi Penyuluh Agama”, 10.

4Jawatan adalah Kantor Wilayah Kementerian Agama di Provinsi dan Kabupaten untuk istilah sekarang ini yang digunakan. 
sebagai jabatan fungsional. Sehingga diterbitkannya secara resmi Keputusan Presiden No 87 Tahun 1999 tentang Rumpun Jabatan Fungsional Pegawai Negeri Sipil, yang menetapkan bahwa Penyuluh Agama adalah jabatan fungsional pegawai negeri yang termasuk dalam rumpun jabatan keagamaan. ${ }^{5}$

Merujuk pada pengertian Penyuluh Agama Islam, secara terminologi penyuluh terambil dari kata suluh yang berarti penerang, ${ }^{6}$ atau dalam istilah komunikasi penyiaran Islam disebut sebagai individu yang bertugas memberikan penerangan. Kemudian penyuluh dalam istilah agama memiliki akar kata alWad'u yang diartikan dengan sebuah proses penyampaian ajaran Islam oleh siapa yang memiliki kompeten di bidangnya untuk memberikan pembimbingan dan penyuluhan baik itu berupa pembinaan maupun pemberdayaan kepada masyarakat luas, ${ }^{7}$ khususnya dalam kasus penelitian ini ialah masyarakat perbatasan. Adapun terkait dengan peran, tugas dan fungsinya sebagaimana tertaung dalam Peraturan Menteri Agama No 10 tahun 1952, dijelaskan bahwa tugas Penyuluh Agama ialah memberikan penyuluhan agama kepada masyarakat, mulai dari memberikan penyuluhan kepada anggota kepolisian, asramaasrama, rumah-rumah penjara dan tempat lainnya memungkinkan dan memerlukan penyuluhan keagamaan.

Ditinjau dari sasarannya penyuluh agama pada periode awal ternyata tidak disasarkan pada masyarakat umum, melainkan hanya pada kalangan tertentu saja. Objek sasaran yang menjadi fokus penyuluhan pada masa sebelumnya terbagi menjadi dua, yaitu: Difokuskan pada aspek pendidikan, dan difokuskan pada aspek social. ${ }^{8}$ Pada periode awal, bentuk dan model bimbingan penyuluh agama dinilai telah memberikan banyak kontribusi dan perbaikan bagi negara ini. Sehingga

${ }^{5}$ Direktorat Jendral Bimbingan Masyarakat Islam, Jejak Sunyi..., h. 11

${ }^{6}$ Novali, Metode Dakwah Penyuluh Agama Islam dalam Mewujudkan Keluarga Sakinah terhadap Pasangan Calon Suami Istri di Kantor Urusan Agama (KUA), (Jurnal, Konseling Religi; Bimbingan Konseling Islam, Vol. 6, No. 2, Desember 2015), diterbitkan di Pondok Pasantren Darun Najah Mejobo Kudus, h. 412

7 Enjang As dan Abdul Mujib, Dasar-dasar Bimbingan dan Penyuluhan Islam, (Bandung: Sajjad Publishing House, 2009), h. 45

8 Enjang As dan Abdul Mujib.., h. 10 
dinilai oleh pemerintah perlu adanya perhatian khusus dalam hal melakukan perbaikan, peningkatan dan pengembangan kualitas dan kuantitas dari tugas serta fungsi penyuluh agama sangat diperlukan. Tujuannya ialah agar kiprah dan kinerja penyuluh sebagai "Konektor kebaikan, merekatkan hubungan yang harmonis, dan memberikan wawasan keislaman sehingga terwujud Islam yang Rahmatan lil Alamin bagi umat" dapat diwujudkan di Seluruh Nusantara. ${ }^{9}$

Kegiatan penyuluhan dalam konteks disiplin ilmu komunikasi pada hakikatnya merupakan proses hubungan interaksi antara penyuluh dengan binaannya, atau lebih dikenal dengan proses transformasi nilai-nilai kesilaman oleh penyuluh kepada masyarakat binaanya. Sistem proses interaksi ini, dalam ilmu komunikasi biasa dikenal juga dengan istiah pola komunikasi. Secara umum istilah pola komunikasi merupakan sebuah rangkaian sistem gambaran atau rancangan dari kegiatan komunikasi yang berlangsung dalam proses komunikasi. Kemudian melalui pola komunikasi inilah kegiatan penyuluh agama dapat dipetakan kedalam bebrapa bentuk komunikasinya. Sehingga nntnya akan menjadi barometer atau tolak ukur berbedanya komunikasi yang dilakukan oleh penyuluh dalam memberikan binaan kepada masyarakatnya ketika dihadapkan dengan kondisi yang sulit. Seperti kondisi gegrafis, sosial, budaya, Infrastruktur, pendidikan, ekonomi, dan tingkat kesadaran keagamaan masyarakat yang rendah. Sebagaimana melalui kondisi tersebut tentu akan berdampak pada proses pembinaan keagamaan di Daerah yang berbeda pula seperti halnya di daerah perbatasan kalimantan barat khususnya di Kecamatan Sajingan Besar Kabupaten Sambas. Sehingga pola komunikasi yang diterapkan oleh Penyuluh Agama Islam juga pasti berbeda.

Berdasarkan uraian di atas, penelitian tentang Pola komunikasi Penyuluh Agama Islam dalam Membina Masyarakat di Daerah perbatasan Kecamatan Sajingan Besar sangat menarik untuk diteliti, terutama terkait dengan pelaksanaan salah satu tugas dan fungsi pokok Penyuluh Agama Islam, yaitu fungsi konsultatif. Tugas dan fungsi penyuluhan tersebut merupakan salah satu tugas dan fungsi pokok yang menjadi standar kegiatan penyuluhan, baik itu di pusat termasuk juga di daerah-daerah perbatasan. Kemudian

9 Pidato yang disampaikan oleh Prof. Dr. H.M. Machasin, MA. 
melalui penelitian ini diharapkan memilki kontribusi yang signifikan bagi pembangunan di Daerah perbatasan Kecamatan Sajingan Besar khususnya dan di daerah lain umumnya dalam dalam menegakkan nilai-nilai moralitas demi tegaknya NKRI. Mengingat peran Penyuluh Agama Islam dalam melakukan pembinaan kepada masyarakat merupakan upaya yang sangat urgen dalam menunjang pembangunan daerah-daerah perbatasan, khususnya di Kalimantan Barat.

\section{B. Metode Penelitian}

Jenis penelitian yang digunakan adalah penelitian kualitatif dengan kategori penelitian lapangan (Field Research). Terkait dengan penelitian Komunikasi Konsultatif Penyuluh Agama Islam dalam membina masyarakat Perbatasan, maka pendeatan yang dilakukan adalah melalui pendekatan Fenomenologi penyuluh secara subjektif. Mengingat asum dasar pendekatan ini merupakan kemampuan menafsirkan atau menjelaskan tindakan dan pemikiran manusia (dalam hal ini adalah tindakan dan pikiran penyuluh di perbatasan) dengan cara menggambarkan secara komprehensif struktur dasar dari realita yang tampak. ${ }^{10}$

Metode yang digunakan dalam melakukan penelitian ialah Studi Kasus dengan basis Instrumental, karena merupakan sebuah cara kerja penelitian kualitatif paradigma naturalistik dengan pendekatan fenomenologi yang berusaha menguraikan persoalan penelitian kemudian menganalisis persoalan tersebut secara mendalam. Selain itu, cara kerja metode studi kasus merupakan bagian dari paradigma naturalistik dengan pendekatan fenomenologi.11 Adapun data primer dan sekunder diperoleh melalui observasi, wawancara dan dokuementer di analisis berdasarakan teknik analisis deskriptif, sehingga diperoleh data dan hasil analisis lebih akurat dan sesuai fokus permasalahan.

10 Norman K. Denzin dan Yvonna S. Lincoln, Handbook of Qualitative Research, Trj. Dariyatno, dkk, (Yogyakarta: Pustaka Pelajar, 2009), Cet. 1, 335-336

11 Norman K. Denzin dan Yvonna S. Lincoln, Handbook..., h. 301 


\section{Pembahasan}

Komunikasi Penyuluh Agama dalam kegiatan fungsi Konsultatif, pada dasarnya merupakan serangkaian kegiatan penyuluhan secara umum sesuai dengan tugas dan fungsi kepenyuluhan. Tugas dan fungsi pokok seorang penyuluh juga merupakan seorang konselor yaitu orang yang memberikan konsultasi kepada binaanya. Demikian pula dalam perspektif komunikasi kegiatan konselor juga merupakan kegiatan penyampaian informasi yang bertujuan memberikan konseling penyuluhan kepada binaannya. Namun yang membedakan kegiatan konseling (Konsultatif dengan kegiatan penyuluhan lainnya di atur dalam Keputusan Direktur Jenderal Bimbingan Masyarakat Islam ialah pada dimensi substansi isi, proses kegiatan dan pihak yang menjadi konselornya. ${ }^{12}$

Dimensi isi dan pihak yang memberikan konsultasi pada fungsi konsultatif dalam kegiatan penyuluhan secara umum juga bersifat umum, seperti penyuluhan pertanian yang memberikan bimbingan tentang pertanian dan masalah seputar pertanian. Contoh lain masilanya penyuluhan dalam bidang kesehatan akan dilakukan oleh pihak kesehatan yang memberikan bimbingan dan konsultasi tentang kesehatan kepada masyarakat. Demikian pula dengan kegiatan konsultasi dalam penyuluhan keagamaan yang dilkuakan oleh Penyuluh Agama cenderung memberikan penyuluhan kepada masyarakat terkait persoalan sosial keagamaan di masyarakat.

Merujuk pada Keputusan Direktur Jenderal Bimbingan Masyarakat Islam, disebutkan bahwa Pihak yang menjadi

12 Sesuai dengan Keputusan Menteri Negara Koordinator Bidang Pengawasan Pembangunan dan Pendayagunaan Aparatur Negara Nomor 54/Kep/MK.WASPAN/9/1999, adalah melakukan dan mengembangkan kegiatan bimbingan atau Penyuluhan Agama dan Pembangunan melalui bahasa agama. Adapun Tugas dan fungsi yang wajib dilaksanakan oleh Penyuluh Agama Islam sebagaimana telah dijelaskan dalam Keputusan Direktur Jenderal Bimbingan Masyarakat Islam Nomor DJ.III/432 Tahun 2016, Tentang Petunjuk Teknis Pengangkatan Penyuluh Agama Islam Non PNS, bahwa terkait dengan tugas dan fungsi Penyuluh Agama Islam, terdapat tiga fungsi pokok Penyuluh Agama Islam, yaitu fungsi Informatif atau edukatif, konsultatif dan advokatif. 
konselornya atau pihak yang memberikan konsultasi kepada masyarakat ialah seseorang atau sekelompok orang yang ditugaskan untuk membimbing masyarakat tentang sosial keagamaan di masyarakat. Pada konteks penyuluhan keagamaan inilah kemudian disebut dengan istilah Penyuluh Agama Islam dalam menjalankan tugas dan fungsinya. Sebagaimana telah dijelaskan dalam Petunjuk Teknis Pengangkatan Penyuluh Agama Islam Non PNS, bahwa terkait dengan tugas dan fungsi dari Penyuluh Agama Islam diantaranya ialah fungsi Konsultatif. 13

Dimensi lainnya yang membedakan fungsi konsultatif pada kegiatan penyuluhan keagamaan dengan kegiatan penyuluhan lainnya adalah pada proses kegiatan. Telah disebutkan sebelumnya, bahwa dalam fungsi konsultatif Penyuluh Agama Islam ialah memberikan bimbingan kepada masyarakat guna memberikan solusi dalam persoalan sosial keagamaan yang dihadapi oleh masyarakat. Oleh sebab itu, proses kegiatan Konsultatif atau konsultasi disebut juga dengan proses bimbingan dan konseling. Kedua proses kegiatan ini seringkali disebut secara bersamaan, meskipun pada dimensi proses kegiatannya memiliki perbedaan.

Enjang AS menyebutkan, bahwa antara bimbingan dan konseling memiliki dimensi berbeda dari proses kegiatannya. Menurut Enjang AS, proses bimbingan (Guidance) terambil dari akar kata Guid dalam literasi bahasa Inggris yang memiliki arti showing the way (memberikan penunjuk jalan), leading (menuntunkan arah jalan), conducting (memimpin ke arah jalan yang benar), giving instruction (memberikan arahan kepada jalan yang benar), regulating (mengatur agar tetap konsisten di jalan yang benar), governing (memebrikan perintah), dan giving advice (memberikan nasihat yang baik-baik). Sedangkan konseling atau causeling terambil dari kata to counsel yang memiliki arti memberikan nasihat atau anjuran kepada orang lain secara tatap muka, baik itu secara personal maupun kelompok. ${ }^{14}$

13 Keputusan Direktur Jenderal Bimbingan Masyarakat Islam Nomor DJ.III/432 Tahun 2016, Tentang Petunjuk Teknis Pengangkatan Penyuluh Agama Islam Non PNS.

14 Enjang AS dan Abdul Mujib, Dasar-dasar Bimbingan dan Penyuluhan Islam, (Bandung: Sajjad Publishing House, 2009), h. 50-51 
Berdasarkan asumsi dasar tersebut, maka dapat dikatakan bahwa proses kegiatan penyuluh Agama dalam menjalankan fungsi konsultatif bukanlah sekedar memberikan dan menyampaikan informasi. Melainkan merupakan kegiatan bimbingan dan konseling kepada masyarakat binaanya secara menyeluruh, khususnya dalam memebrikan bimbingan dan konseling untuk menyelesaikan persoalan sosial keagamaan yang dihadapi oleh masyarakat binaanya. Sejalan dengan pandangan Prayitno, yang menjelaskan bahwa proses kegiatan penyuluhan cenderung menekankan pada penjelasan dan penerangan tentang sesuatu, sedangkan konseling lebih mengutamakan tentang penanganan dan solusi penyelesaian kasus-kasus..$^{15}$ Kasus yang dimaksudkan pada konteks Penyuluh Agama adalah kasus sosial keagamaan di masyarakat, seperti kasus perceraian, kenakalan remaja, kriminlitas dan kasusu lainnya, khususnya di daerah perbatasan.

Terkait dengan kegiatan fungsi konsultatif yang dilakukan oleh Penyuluh Agama di Daerah perbatasan Kecamatan Sajingan Besar sebagai objek penelitian. Menurut hasil observasi dan wawancara di lapangan, beberapa bentuk kegiatan yang dilakukan diantaranya, secara umum melalui dua bentuk kegiatan, yaitu konseling dan kajian keagamaan. Adapun dalam perspektif komunikasi maka pola komunikasi yang dilakukan oleh penyuluh dalam menjalankan fungsi konsultatif dapat diketahui melalui beberapa aspek, yaitu Jenis Kegiatan yang dilakukan, Pesan (Massage) Komunikasi yang disampaikan, Media (Chanel), Bentuk Komunikas yang digunakan (Model Communication).

Menurut data ditemukan beberapa bentuk kegiatan yang dilakukan oleh penyuluh dalam melakukan kegiatan konsultatif, yaitu pertama penyuluh di perbatasan melakukan komunikasi secara personal dengan masyarakat melalui beberapa pendekatan, di antaranya bertemu secara langsung dengan mendatangi rumah-rumah warga, ada juga dilakukan disela-sela melakukan pekerjaan sehari-hari di kebun, selanjutnya saat diskusi-diskusi santai di warung-warung, atau bahakan warga sendiri yang mendatangi penyuluh untu mendapatkan solusi persoalan sosial keagamaan. Kedua bentuk komunikasi kelompok

${ }^{15}$ Prayitno, Pengantar Bimbingan dan Konseling, (Jakarta: Rajawali, 2008), h. 23 
yang dilakukan melalui beberapa kegiatan, diantaranya bentuk kegiatan berupa taklim atau kajian mingguan yang sudah terjadwal baik itu setiap minggu, setiap bulan atau bahkan kajian tahunan. Mulai dari kegiatan BKMT, Taklim atau Ceramah dan Tabligh Akhbar. Adapun kegiatan konsultasi dalam beberapa bentuk kegiatan tersebut pada umumnya di lakukan di sela-sela acara dan setelah acara, dimana masyarakat (Binaan) yang hadir diberikan wktu untuk mengajukan pertanyaan, menyampaikan persoalan yang dihadapi dalam kehidupan sehari-hari.

Sedangkan pesan yang disampaikan dalam kegiatan bimbingan dan konseling tidak lepas dari tiga aspek yaitu aqidah, syariat atau fiqih, dan Muamalah. Materi Aqidah dalam kegiatan penyuluhan konsultatif merupakan materi (pesan komunikasi) yang utama dalam meberikan bimbingan dan konseling ke masyarakat perbatasan di Kecamatan Sajingan Besar Sambas, karena sebagaian besar masyarakat binaan ialah mualaf. Beberapa materi aqidah yang sering dipersoalkan oleh masyarakat adalah tentang Eksistensi "Allah SWT" Tuhan Rabbul 'Alalamin. Beberpa persoalan yang menjadi pertanyaan masyarakat pada umumnya ialah "Bagaimana menurut bapak (Penyuluh) tentang Tuhan?", "Ada berapa Jumlah Tuhan dalam Islam?".

Sebagai seorang penyuluh selain memberikan penerangan tentang pondasi dasar dalam beragama (Aqidah) maka pesan selanjutnya yang sering disampaikan salama memberikan konseling ialah materi tentang syariat atau persoalan fiqih. Mengingat masyarakat binaan di perbatasan ialah masyarakat mualaf, sudah tentu asumsinya sangat minim pengetahuan mereka tentang syariat dan hukum fiqih yang mengatur bagaimana mereka beribadah, Bagaimana Pelaksanaan Khutbah dan Shalat Jumat, Batas Muhrim dan Non Muhrim dalam Islam, Kewajiban Suami Istri dan Hukum Nikah Sirri, Hukum orang yang Masuk Islam (Mualaf), Hukum orang non-muslim memandikan keluarganya yang Muslim, dan Hukum orang yang memandikan Jenazah tetapi tidak bisa menjaga rahasia si Mayit. ${ }^{16}$

Bagi masyarakat perbatasan (Khususnya Mualaf) materi

16 Laporan Penyuluh Agama Islam Kementerian Agama Kabupaten Sambas Tahun 2017, tentang rekapitalsi Lembar Laporan Konsultasi. 
fiqih ini merupakan persoalan yang sering disampaikan dalam berkonsultatif dengan penyuluh, baik itu dalam bentuk komunikasi personal atau komunikasi kelompok yang telah dijeslakan pada pembahasan sebelumnya. Pesan komunikasi ketiga yang sering disampaikan dalam menberikan konsleing ialah tentang muamalah, yaitu berkaitan tata cara berinteraksi, bergaul atau betetangga dengan orang lain yang berbeda keyakinan, berbeda suku, berbeda budaya sesuai dengan tuntunan ajaran islam. Menurut data kependudukan, masyarakat perbatasan di Sajingan Besar tergolong masayarakat yang pluralisme (heterogen). ${ }^{17}$ Mayarakat muslim merupakan mayarakat yang minoritas di banding dengan msyarakat yang lainnya. Sehingga persoalan sosial keagamaan tentang bagaimana tata cara berinteraksi dengan masyarakat yang berbeda suku, Toleransi Antar Umat Beragama, Hukum orang bertato dalam Islam, Tanggapan Non-Muslim terhadap umat Muslim di Sajingan Besar, Hukum Vaksin Balita (Halal atau Haram), dan Hukum membela orang non-muslim sering dikonsultasikan kepada penyuluh.

Media yang digunakan dalam proses kegiatan konsultatif sifatnya berbeda dengan fungsi lainnya (Tranformatif dan Advkatif). Karena pola komunikasi konsultatif pada umumnya memberikan bimbingan dan konseling secara langsung (Pace to Pace). Oleh sebab itu komunikasi yang digunakan juga sifatnya personal. Kecuali kegiatan yang sifatnya kelompok yaitu konsultasi di KUA, Masjid dan tempat pertemuan lainnya. Beberpa media yang digunakan diantaranya untuk menyampaikan pesan seperti Al-Qur'an, Kitab-Kitab Hadis, Buku-buku.

17 Begitu pula dengan Jumlah Penduduk menurut Agama yang dianut. Penduduk Kecamatan Sajingan Besar terdiri dari empat Agama kepercayaan yang dianut, yaitu penduduk yang menganut Agama Islam berjumlah 938 Jiwa, Khatolik 7.985 Jiwa, Protestan 1.836 Jiwa dan 9 Jiwa yang beragama Budha. Apabila dibandingkan dengan agama lain, Muslim di Kecamatan Sajingan Besar merupakan penduduk minoritas kedua setelah Budhis. Secara keseluruhan penduduk di Kecamatan Sajingan Besar adalah penduduk yang beragama Khatolik dan Protestan. Berikut tabel tentang Penduduk Kecamatan Sajingan Besar, menurut jenis kelamin dan kewarganegaraan, serta menurut agama yang dianut. Lihat, Monografi Data Kependudukan Kecamatan Sajingan Besar Tahun 2017. 
Berdasarkan hasil observasi dan wawancara di lokasi penelitian, maka bentuk komunikasi Penyuluh Agama Islam dalam menjalankan fungsi konsultatif dapat dideskripsikan menjadi sebuah pola komunikasi. Pola komunikasi ialah, serangkaian proses komunikasi yang terjadi melalui beberapa tahapan sehingga membentuk sebuah bentuk atau model dari cara kerja sebuah proses yang menggambarkan kompleksitas hubungan antar unsur-unsur yang terkait di dalamnya. ${ }^{18}$ Adapun untuk mengtahui bagaiamana mekanismenya sebuah pola komunikasi itu terbentuk, dapat di lihat dua aspek pembentuk pembentuknya dalam proses komunikasi konsultatif yang dilakukan oleh Penyuluh di perbatasan, yaitu aspek arah pesan informasi dan subjetivitas penyuluh (atribusi).

Berdasarkan hasil analisis data penelitian, apabila ditinjau dari teori arah informasi bentuk pola yang digunakan cenderung bersifat dua arah informasi, yaitu bentuk pola komunikasi dengan Pola Bintang dan Pola Rantai. Konsep dasar pola Bintang, menurut H.A.W Widjaja adalah proses komunikasi yang menggambarkan arah informasi dari semua anggota, ${ }^{19}$ yang artinya bahwa arah informasi yang terbangun terdiri dua arah atau secara timbal balik. Berdasarkan pola bintang yang digunakan tergambar, bahwa arah informasi tidak terpaku kepada penyuluh Agama. Tetapi bisa saja dari masyarakat yang menyampaikan informasi terlebih dahulu kepada Penyuluh Agama, kemudian Penyuluh Agama merespon dan menanggapi keluhan, pertanyaan dan permintaan dari masyarakat mengenai persoalan keagamaan yang dihadapi. Untuk arah informasi seperti ini, sering dilakukan oleh Penyuluh Agama dengan Masyarakat di tempat tinggal Penyuluh Agama atau di Kantor KUA, di Masjid, dan ditempat Pengajian, karena sifatnya masyarakat yang memulai proses konseling.

Sebaliknya, proses arah informasi di mulai dari Penyuluh Agama menyampaikan atau memberikan bimbingan kepada masyarakat, baik itu datang secara langsung ke rumah masyarakat, di warung-warung dan di tempat kerja. Bentuk

18 Wiryanto, Pengantar Ilmu Komunikasi, (Jakarta: Gramedia Widiasavina, 2004), h. 9

19 H.A.W. Widjaja, Ilmu Komunikasi Pengantar Studi, (Jakarta: Rineka Cipta, 2000), h. 102-103 
kegiatan inilah yang disebutkan dengan bentuk kegiatan silaturahmi penyuluh ke masyarakat. Berikut gambar arah informasi dari pola bintang dalam proses komunikasi Penyuluh Agama Islam membina masyarakat di Daerah perbatasan sesuai fungsi konsultatif.

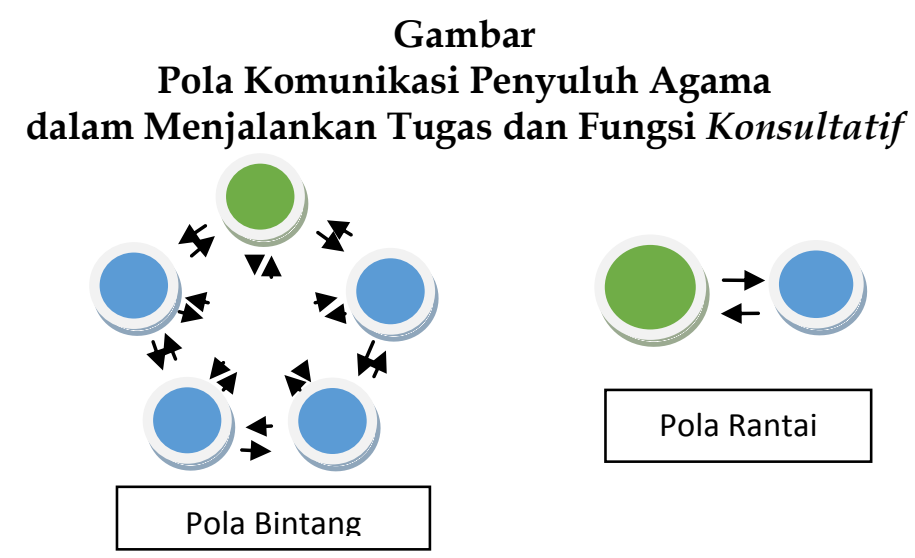

Berdasarkan kedua pola arah informasi dalam proses konsultatif di atas, bentuk komunikasi yang terjadi terbagi menjadi dua, yaitu secara personal dan secara kelompok. Bentuk komunikasi secara personal, pola komunikasi yang digunakan cenderung pada pola rantai, sedangkan bentuk komunikasi kelompok pola komunikasi yang digunakan lebih pada pola bintang. Penggunaan kedua bentuk pola komunikasi dalam proses penyuluhan konsultatif sama halnya dengan fungsi-fungsi lainnya, yaitu sangat dipengaruhi oleh subjektivitas komunikator atau disebut dengan teori atribusi. Konsep dasar teori ini menurut Fritz adalah bertujuan untuk menganalisis faktor-faktor yang menyebabkan seseorang yang melakukan tindakan. ${ }^{20}$

Merujuk pada teori subjektivitas Penyuluh Agama di Daerah perbatasan beberapa faktor mempengaruhi bentuk pola komunikasi yang digunakan dalam menjalankan fungsi konsultatif, di antaranya terbagi dua yaitu internal dan ekternal. Secara internal faktor penyebab yang mempengaruhi tindakan Penyuluh Agama dalam melakukan fungsi konsultatif ialah

20 Litlejohn dan Foss, Theories of Human Communication. Trj. Muhammad Yusuf Hamdan, (Jakarta: Salemba Humanika, 2014), h. 102 
dikarenakan faktor psikologi komunikan (Penyuluh). Dimensi faktor ini diantaranya berkaitan dengan pribadi penyuluh agama yang merasakan kedekatan dengan masyarakat, karena menjadi bagian dari masyarakat perbatasan di Kecamatan Sajingan Besar.

Walaupun Penyuluh Agama di daerah perbatasan bukanlah semua penduduk asli di daerah tersebut, tetapi ikatan perasaan dan moral secara batiniah selaku sesama muslim sangatlah tinggi. Sehingga proses konseling dilakukan dalam bentuk silaturahmi, yaitu masyarakat datang bersilaturahmi dengan penyuluh atau sebaliknya penyuluh yang datang ke rumah masyarakat untuk melakukan proses bimbingan dan konseling kepada masyarakat yang menghadapi masalah sosial keagamaan sering kali dilakukan secara efektif dan konsultatif.

Adapun Faktor secara ekternal yang juga mempengaruhi ialah situasi lingkungan atau kondisi objektif daerah perbatasan. Kondisi lingkungan juga memberikan pengaruh kepada penyuluh dalam melakukan penyuluhan. Aspek penting yang dimaksudkan ialah berkaitan dengan beberapa hal, diantaranya lingkungan yang berbeda dengan daerah lain, kultur budaya yang berbeda dengan daerah lain, kontruksi sosial yang terbentuk di daerah perbatasan.

Kondisi lingkungan di daerah perbatasan ditinjau dari aspek geografisnya adalah daerah yang terletak jauh dari perkotaan, terletak di daerah perbukitan dan pegunungan, serta tata letak pemukiman yang sifatnya menyebar tidak merata, sehingga sangat berpengaruh terhadap penentuan pola komunikasi. Terutama dalam proses kegiatan fungsi konsultatif, seperti dilakukannya kunjungan penyuluh ke rumah-rumah masyarakat atau sebaliknya dalam komunikasi personal, atau dilakukannya proses konsultasi atau konseling dalam kegiatan pengajian dan taklim. Mengingat sangat sulit sekali akses untuk bertemu secara rutin dengan masyarakat, karena kondisi lingkungan tidak memungkinkan sehingga akan memberikan pengaruh tersendiri dalam proses komunikasi konsultatifnya.

Faktor lain yang menyebabkan pola komunikasi digunakan dalam proses penyuluhan fungsi konsultatif adalah sosial budaya masyarakat daerah perbatasan. Masyarakat perbatasan di Kecamatan Sajingan Besar dikenal sebagai masyarakat yang mengandalkan pada mata pencaharian dengan mengolah lahan 
menjadi lahan pertanian dan perkebunan. Sehingga banyak waktu dan tenaga yang dihabiskan untuk bekerja di luar rumah baik itu di kebun dan di ladang. Mengingat kesibukan yang cukup padat setiap harinya, maka juga akan mempengaruhi intensitas dan rutinitas dalam proses konsultatifnya.

Selanjutnya, Faktor lain yang menjadi alasan mengapa dalam beberapa kesempatan masyarakat melakukan kegiatan konsultatasi pada penyuluh, tanpa harus menunggu waktu tertntu. Terutama pada saat istirahat atau pulang kerja dari kebun, baik itu di kebun atau diwarung-warung proses konsultasi tentang persoalan sosial keagamaan dilakukan. Pada kondisi seperti inilah sering terjadi proses komunikasi dengan pola rantai yang digunakan oleh Penyuluh Agama Islam kepada Masyarakat di Daerah perbatasan, karena sifat arah pesannya dan bentuk komunikasinya terjadi secara personal. Waktu kegiatannya juga tidak terjadwal seperti kegiatan lainnya.

Merujuk pada aspek psikologis dan mekanisme proses komunikasi antara penyuluh dengan masyarakat perbatasan di Sajingan Besar, maka dapat ditarik sebuah kesimpulan bahwa pola komunikasi yang dibangun dalam menjalankan fungsi Konsultatif cenderung bersifat personal dan dialogis. Adapaun sifat arah pesan yang dibangun tergambar melalui pola bintang dan rantai cenderung dua arah. Melalui kedua pola komunikasi tersebut, sehingga terbangun rasa kedekatan dan efektivitas penyuluhan terbangun dengan baik dalam kegaiatan memberikan bimbingan dan konseling kepada masyarakat perbatasan. Karena secara psikologis Penyuluh Agama memahami betul kondisi sosial budaya yang ada di Daerah perbatasan Kecamatan Sajingan Besar.

Sedangkan, faktor lain ialah dikarenakan kondisi geografis yang tidak memungkinkan untuk melakukan kegiatan bimbingan dan konseling secara rutin dalam bentuk kegiatankegiatan formal lainnya, sehingga memungkinkan Penyuluh Agama sebisa mungkin memanfaatkan waktu dan kesempatan secara efisien ketika betemu sapa dengan masyarakat di berbagai kesempatan. Oleh sebab itu, pola komunikasi dengan pola bintang dan rantai merupakan pola efektif dalam melakukan proses penyuluhan konsultatif. Mengingat dalam proses konsultatif bagi masyarakat di Daerah perbatasan berbeda dengan 
daerah lainnya, sehingga sangat memerlukan perhatian lebih agar peran penyuluh sebagai konselor, pembimbing, penerang, motivator, fasilitator dan inovator, ${ }^{21}$ dan dapat dijalankan baik.

Berdasarkan hasil analisis penelitian terhadap proses komunikasi yang dilakukan oleh Penyuluh Agama Islam di salah satu Daerah Perbatasan di kalimantan Barat tersebut, maka dapat di deskripsikan melalui skema kerangka bentuk dan model proses komunikasi konsultatif penyuluh agama islam dalam melaksakan tugas dan fungsi penyuluhan di daerah perbatasan.

\section{Gambar \\ Skema Pola Komunikasi Penyuluh Agama Islam dalam Malaksanakan Fungsi Konsultatif}

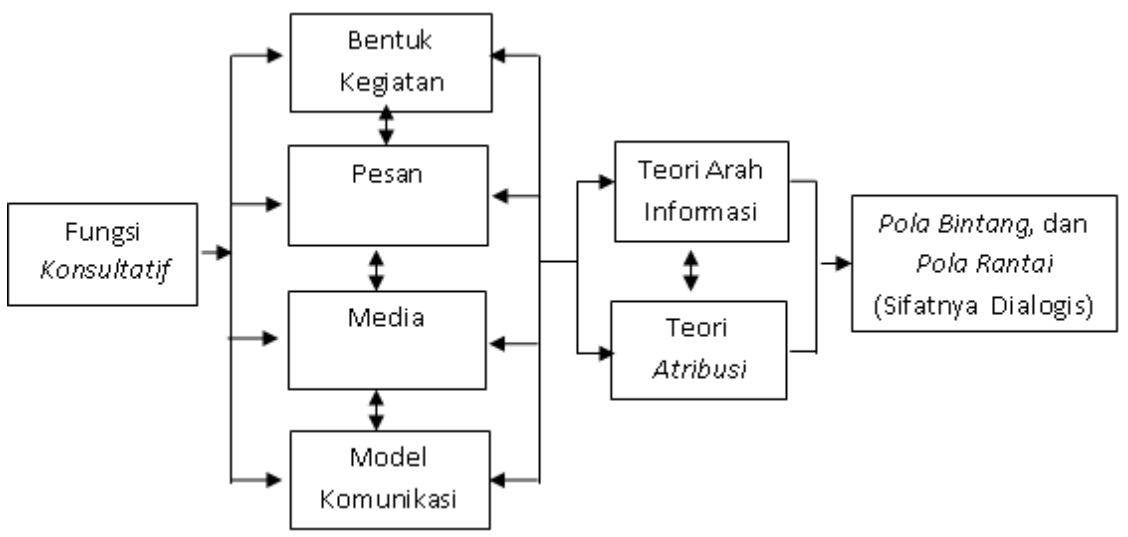

\section{Simpulan}

Berdasarkan hasil pembahasan, maka dapat disimpulkan bahwa Komunikasi Penyuluh Agama Islam dalam melaksanakan tugas dan fungsi pokok penyuluhan konsultatif kepada masyarakat di Daerah Perbatasan Kecamatan Sajingan Besar Kabupaten Sambas KaliMnatan Barat, secara sistematis terjalin cenderung bersifat personal dan kelompok yang dialogis. Sifat sistematis tersebut, secara empirik terdeskripsikan melalui pola komunikasi yang digunakan oleh penyuluh di lapangan, yaitu

21Zulkarnain Nasution, Prinsip-prinsip Komunikasi untuk Penyuluhan, (Jakarta: Fakultas Ekonomi Universitas Indonesia, 1990), h. 19 
Pola Rantai dan Pola Bintang. Faktornya ialah dikarenakan subjektivitas aktor komunikasi (Penyuluh dan Masyarakat Bianaan) yang terbangun mempengaruhi proses penyuluhan, baik itu situasional kondisi lingkungan geografisnya, kepribadian dan sosial budaya masyarakatnya. Sehingga, kecenderuangan pola komunikasi yang terbentuk juga lebih menekankan pada aspek sosial budaya dan keagamaan masyarakat di daerah perbatasan.

Merujuk pada simpulan di atas, perlu disampaikan bebrapa saran atau rekomendasi. Pertama, diharapkan perhatian khusus dari pihak yang memiliki wewenang untuk membuat kebijakan preventif guna terjaganya masyarakat dari krisis moralitas dan Rasa Nasionalisme di daerah perbatasan khususnya di Kecmatan Sajingan besar Kabupaten Sambas Kalimanatn Barat. Kedua, perlu adanya lagi peningkatan kualitas dan kuantitas Penyuluh Agama Islam di daerah perbatasan demi terwujud Islam yang Rahmatan il Alamin bagi umat dan keutuhan NKRI. Ketiga, penelitian ini masih sangat memungkinkan untuk dikembangkan dan dikaji lebih jauh lagi menjadi pola komunikasi lainnya, baik itu dari segi teoritis, metodologis dan pembahasannya.

\section{Daftar Pustaka}

Basit, Abdul. Tantangan Profesi Penyuluh Agama Islam dan Pemberdayaannya. Jurnal Dakwah, Vol. XV, No. 1, Tahun 2014, Jurusan Dakwah Sekolah Tinggi Agama Islam Negeri Purwokerto.

Denzin, Norman K. dan Yvonna S. Lincoln. Handbook of Qualitative Research, Trj. Dariyatno, dkk. Yogyakarta:

Pustaka Pelajar, 2009. Cet. 1.

Direktorat Jendral Bimbingan Masyarakat Islam. Jejak Sunyi Penyuluh Agama. Majalah Bimas Islam Kementerian Agama RI, edisi No. 4/III/2016), 6.

Enjang AS dan Abdul Mujib. Dasar-dasar Bimbingan dan Penyuluhan Islam. Bandung: Sajjad Publishing House, 2009. 
Keputusan Direktur Jenderal Bimbingan Masyarakat Islam Nomor DJ.III/432 Tahun 2016, Tentang Petunjuk Teknis Pengangkatan Penyuluh Agama Islam Non PNS.

Keputusan Direktur Jenderal Bimbingan Masyarakat Islam Nomor DJ.III/432 Tahun 2016, Tentang Petunjuk Teknis Pengangkatan Penyuluh Agama Islam Non PNS.

Keputusan Menteri Negara Koordinator Bidang Pengawasan Pembangunan dan Pendayagunaan Aparatur Negara Nomor 54/Kep/MK.WASPAN/9/1999.

Laporan Penyuluh Agama Islam Kementerian Agama Kabupaten Sambas Tahun 2017, tentang rekapitalsi Lembar Laporan Konsultasi.

Litlejohn dan Foss. Theories of Human Communication. Trj. Muhammad Yusuf Hamdan. Jakarta: Salemba Humanika, 2014.

Monografi Data Kependudukan Kecamatan Sajingan Besar Tahun 2017.

Nasution, Zulkarnain. Prinsip-prinsip Komunikasi untuk Penyuluhan. Jakarta: Fakultas Ekonomi Universitas Indonesia, 1990.

Novali. Metode Dakwah Penyuluh Agama Islam dalam Mewujudkan Keluarga Sakinah terhadap Pasangan Calon Suami Istri di Kantor Urusan Agama (KUA). Jurnal, Konseling Religi; Bimbingan Konseling Islam, Vol. 6, No. 2, Desember 2015. diterbitkan di Pondok Pasantren Darun Najah Mejobo Kudus.

Pidato yang disampaikan oleh Prof. Dr. H.M. Machasin, MA.

Prayitno. Pengantar Bimbingan dan Konseling. Jakarta: Rajawali, 2008.

Widjaja, H.A.W. Ilmu Komunikasi Pengantar Studi. Jakarta: Rineka Cipta, 2000.

Wiryanto. Pengantar Ilmu Komunikasi. Jakarta: Gramedia Widiasavina, 2004. 